\title{
Extended grazing systems for improving eco- nomic returns from Nebraska sandhills cow/calf operations
}

\author{
DON C. ADAMS, RICHARD T. CLARK, SEAN A. COADY, JAMES B. LAMB, AND \\ MERLYN K. NIELSEN
}

Clark and Adams are associate professors, and Coady and Lamb are research associates, University of NebraskaLincoln, Institute of Agriculture and Natural Resources, West Central Research and Extension Center, Route 4, Box 46A, North Platte 69101, Nielsen is professor University of Nebraska-Lincoln 68583.

\begin{abstract}
Three winter treatments were cross classified with 2 spring treatments to create 6 feeding and grazing systems utilizing Nebraska sandhills range and subirrigated meadow forage. Systems were evaluated with multiparous crossbred beef cows over 4 years (240 head beginning year 1). Systems were: 1) grazing range during winter; 2) grazing subirrigated meadow during winter; and 3) full feed of meadow hay during winter; in combination with either: a) full feed of subirrigated meadow hay during May, or b) grazing subirrigated meadow during May. From June through November all cows grazed range. The feeding and grazing systems were compared with selected linear contrasts and evaluated with respect to variable input prices. Some differences in cow body weight and body condition occurred but differences were considered small. Throughout the study, cows on all systems generally maintained a body condition score of about 5 (1 to 9 scale) year long. Inputs of hay were reduced by grazing range or subirrigated meadow during winter and during May without affecting pregnancy rate. Weaning weight of calves was increased $5.0 \mathrm{~kg}$ by grazing meadow during May compared to feeding hay during May. When opportunity costs were included in the analysis, the most profitable system involved grazing subirrigated meadow during winter and during May. Grazing subirrigated meadow during May enhanced the profitability of all wintering systems.
\end{abstract}

Key Words: rangeland, subirrigated meadow, beef cattle, partial budgets, stochastic dominance, net returns

Profitability of the beef cattle industry depends in part on its ability to compete with other meat industries. To compete effectively, the industry must continue to lower costs per pound of meat produced (Barkema and Drabenstott 1990). Feeder cattle (i.e., weaned calves) account for about three-fifths of the total cost of finished cattle. Feed costs make up about one-fourth of the costs of raising feeders (Barkema and Drabenstott 1990). An Integrated Resource

\footnotetext{
The authors wish to acknowledge the High Plains Climate Center at the University of Nebraska-Lincoln for assistance in preparing and providing climate data for this study. Published with the approval of the director of the Nebraska Agr. Res. Div. as Joumal Ser. no. 10501 .

Manuscript accepted 15 Jan. 1994.
}

Management project in Nebraska found that harvested forage costs ranged from 18 to $24 \%$ of total cost per weaned calf (Rasby et al. 1989). Reducing the feeding of harvested forage while maintaining or enhancing cow performance could substantially increase the profitability of cow/calf producers and lower overall costs of beef production. Greater reliance on the cow rather than machines for forage harvesting is one method for reducing feed costs (D'Souza et al. 1990). Extending winter grazing on rangeland and/or subirrigated meadows would reduce inputs of harvested forage. In the Nebraska sandhills, a further savings in feed costs might also be realized by grazing subirrigated meadows in early spring, a time when upland range is dormant and hay is usually fed. A survey of Nebraska Sandhills ranches estimated that about $50 \%$ contained some subirrigated meadows (Clark and Coady 1992); only 14\% of those with meadows grazed them in the spring (Coady and Clark 1993).

A 4-year study was initiated in 1988 to determine the effects of extending common grazing dates for cattle by grazing upland range during winter and subirrigated meadows in May. The 2 major objectives were: 1) to measure the impacts on cow/calf production under alternative forage treatments during the winter (gestation) and between calving and breeding (prebreeding), and 2 ) evaluate the impacts of the alternative forage treatments on costs and returns to a cow/calf producer. Our hypothesis was that by extending the grazing season in winter and spring, profitability would be increased over traditional systems which use a greater amount of harvested forage.

\section{MATERIALS AND METHODS}

\section{Forage and Cattle Procedures}

Two-hundred-forty crossbred cows, 3 to 7 years of age, were randomly assigned within age during 1988 to 3 winter treatments and 2 spring (prebreeding) treatments which were cross classified to create 6 forage systems ( $3 \times 2=6$ systems; Table 1 ). Treatments were replicated over 4 years. Cows were 1/4 Hereford, 1/4 Angus, 1/4 Simmental and 1/4 Gelbvieh. Year-long management was comprised of 4 periods: a) winter (gestation), 15 November-1 March; b) calving, 2 March-30 April; c) prebreeding, 1 May-31 May; and d) breeding and summer management, 1 June-15 November. A 60-day breeding season began 15 June each year. Winter treatments were: 1) 1.36 $\mathrm{kg} / \mathrm{cow}$ of a commercial $32 \%$ crude protein ( $0 \%$ non-protein nitrogen) supplement fed every other day to cows grazing range, 2) graz- 
Table 1. Treatment (system) description with corresponding management period.

\begin{tabular}{|c|c|c|c|c|}
\hline Treatment & $\begin{array}{c}\text { Gestation } \\
15 \text { Nov.-1 Mar. }\end{array}$ & $\begin{array}{c}\text { Calving } \\
1 \text { Mar.-1 May }\end{array}$ & $\begin{array}{l}\text { Prebreeding } \\
1 \text { May-1 Jun. }\end{array}$ & $\begin{array}{c}\text { Breeding- Weaning } \\
1 \text { Jun.-15 Nov. }\end{array}$ \\
\hline (1) & & 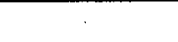 & & \\
\hline $\begin{array}{l}\text { Winter-range } \\
\text { May-hay }\end{array}$ & Range & Hay & Hay & Range \\
\hline (2) & & & & \\
\hline $\begin{array}{l}\text { Winter-range } \\
\text { May-meadow }\end{array}$ & Range & Hay & Meadow grazing & Range \\
\hline (3) & & & & \\
\hline $\begin{array}{l}\text { Winter-hay } \\
\text { May-hay }\end{array}$ & Hay & Hay & Hay & Range \\
\hline (4) & & & & \\
\hline $\begin{array}{l}\text { Winter-hay } \\
\text { May-meadow }\end{array}$ & Hay & Hay & Meadow grazing & Range \\
\hline (5) & & & & \\
\hline $\begin{array}{l}\text { Winter-meadow } \\
\text { May-Hay }\end{array}$ & Meadow grazing & Hay & Hay & Range \\
\hline $\begin{array}{l}\quad(6) \\
\text { Winter-meadow } \\
\text { May-Meadow }\end{array}$ & Meadow grazing & Hay & Meadow grazing & Range \\
\hline
\end{tabular}

ing subirrigated meadow, with the same protein supplement as in treatment 1 fed at $1.36 \mathrm{~kg}^{\circ} \mathrm{cow}^{-1} \cdot \mathrm{day}^{-1}$ during days of heavy snow or sub-zero temperature, and 3) meadow hay (approximately $8.0 \%$ crude protein) fed daily ad libitum. Spring treatments consisted of: 1) meadow hay (about $8.0 \%$ crude protein) offered daily ad libitum, and 2) grazing new growth on subirrigated meadow. The appropriate amount of supplement was fed by a pickup truck with a supplement feeder equipped with an electronic scale. Hay was fed from stacks (about 6.4 metric ton) of long stem hay by a stack mover/feeder pulled by a 100-horsepower tractor; during 1991 and 1992 the feeder/stacker was equipped with an electronic scale to weigh the amount of hay fed.

The study site was sands, choppy sands, and subirrigated meadow sandhill sites on the University of Nebraska-Lincoln Gudmundsen Sandhills Laboratory near Whitman, Nebraska. The dominant grass species were blue grama [Bouteloua gracilis (H.B.K.) Lag.ex Griffiths], little bluestem [Schizachyrium scoparium (Michx.) Nash], prairie sandreed [Calamovilfa longifolia (Hook.) Scribn.], sand bluestem (Andropogon hallii Hack.), switchgrass (Panicum virgatum L.), sand lovegrass [Eragrostis trichodes (Nutt.) Wood], and indiangrass [Sorgastrum nutans (L.) Nash]. Common forbs and shrubs include western ragweed (Ambrosia psilostachya Dc.) and leadplant [Amorpha canescens (Nutt.) Pursh].

The subirrigated meadow soils are classified as Gannett-Loup fine sandy loam (coarse-loamy mixed mesic Typic Haplaquoll). Dominant meadow vegetation was smooth bromegrass (Bromus inermis Leyss.), redtop (Agrostis stolonifera L.), timothy (Phleum pratense L.), slender wheatgrass [Agropyron trachycaulum (Link) Malte], quackgrass [Agropyron repens (L.) Beauv.], Kentucky bluegrass (Poa pratensis L.), prairie cordgrass (Spartina pectinata Link), and several species of sedges (Carex spp.) and rushes (Juncus spp. and Eleocharis spp.). Less abundant grass species were big bluestem (Andropogon geradii Vitman), indiangrass, and switchgrass. Legumes were a minor component of the vegetation.

Precipitation was measured at the Gudmundsen Sandhills Laboratory at an automated weather data network station operated by the High Plains Climate Center at the University of Nebraska-
Lincoln.

Cow body weights and body condition scores were taken precalving (1 March), prebreeding (1 June), and at weaning (15 October). Body condition scores were assigned using visual observations and a scoring system from 1 to 9 , with 1 being extremely thin and 9 being extremely fat. Calf weights were taken at birth, 1 June, and at weaning. Cows were pregnancy checked at weaning by rectal palpation, and open cows were removed from the study. Replacement cows were not added to the study.

Treatment, year, and treatment $X$ year were included in the analysis of variance for cow traits; sex of calf, sex of calf $X$ year, and sex of calf $X$ treatment were included in the analysis of calf traits.Pregnancy rates were transformed to logits (Cox 1970), analyzed by weighted least squares, and tested using the chi-square distribution. Treatments were compared with orthogonal contrasts (Table 2); error terms were treatment $X$ year and treatment $X$ year $X$ sex of calf for cow and calf traits, respectively.

Table 2. Linear contrasts for treatment comparisons.

\begin{tabular}{cll}
\hline \hline Contrast & \multicolumn{1}{c}{ Description } & \multicolumn{1}{c}{ Treatment } \\
\hline 1 & $\begin{array}{l}\text { No May grazing vs May grazing } \\
\text { Winter-hay vs Winter-range }+ \\
\text { Winter-meadow }\end{array}$ & $1+3+5$ vs $2+4+6$ \\
3 & Winter-range vs Winter-meadow & $1+2$ vs $5+6$ \\
4 & $\begin{array}{l}\text { Interaction: did performance on May } \\
\text { treatment depend on winter } \\
\text { treatment (i.e., grazing or hay)? }\end{array}$ & $2+3+6$ vs $1+4+5$ \\
& $\begin{array}{l}\text { Interaction: did performance on May } \\
\text { treatment depend on winter grazing } \\
\text { treatment (meadow or range)? }\end{array}$ & $1+6$ vs $2+5$ \\
\hline
\end{tabular}

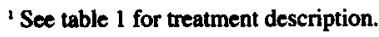




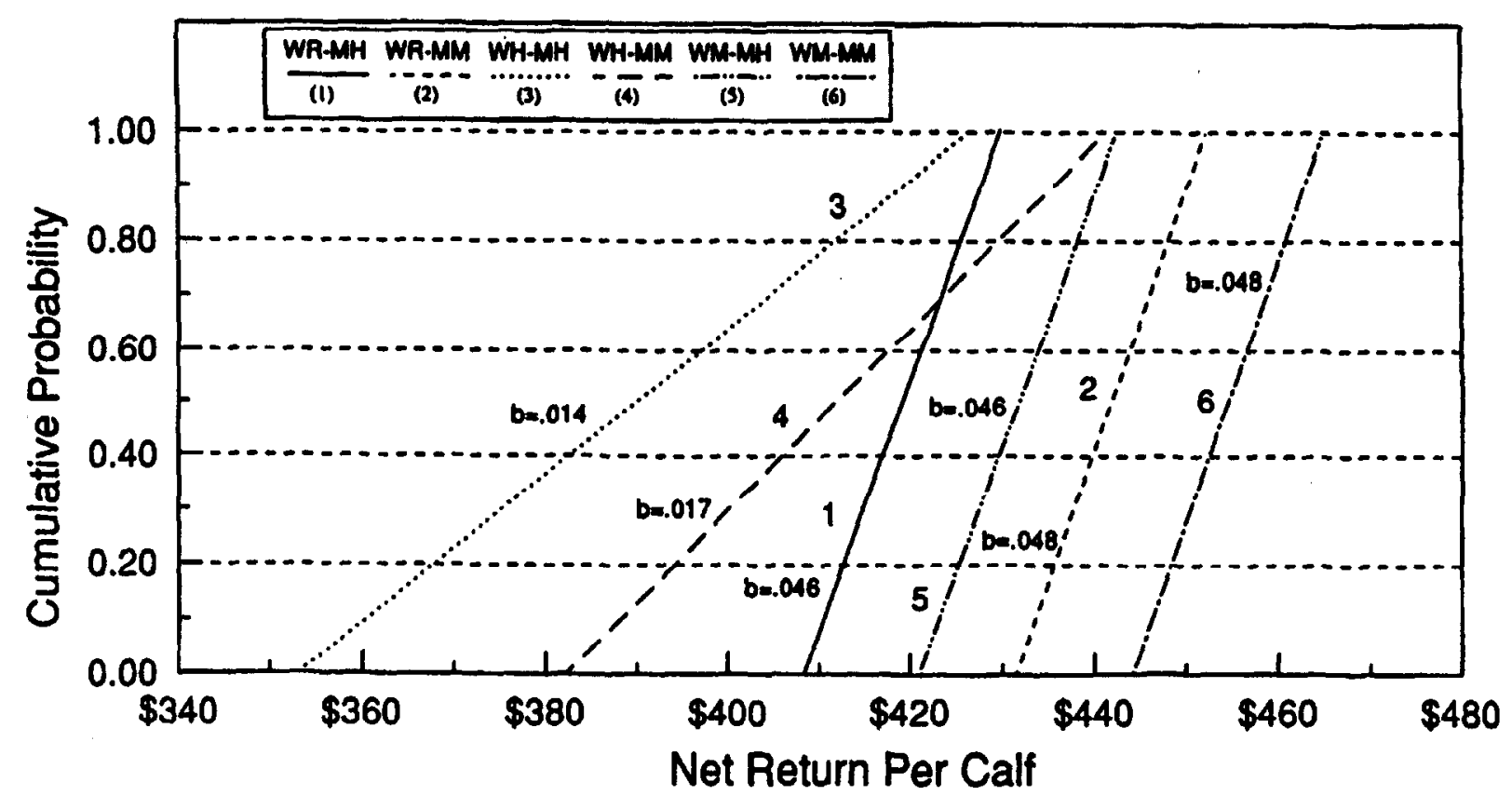

\author{
WR $=$ Winter Range, $W H=$ Winter Hay, $W M=$ Winter Meadow \\ $\mathrm{MH}=$ May Hay, $\mathrm{MM}=$ May Meadow
}

Fig. 1. Cumulative distribution of net returns for 6 forage and grazing systems.

\section{Economic Procedure}

Each treatment was evaluated for its potential effect on net returns. The analysis was based on a ranching operation with a resource endowment sufficient to support each forage management alternative. The economic analysis was based on sensitivity of the forage management alternatives to input price variability and was conducted using partial budgeting. Animal performance was incorporated into the economic analysis only through calf production because pregnancy rate was similar $(P>0.10)$ among treatments.

The 4 years of calf weaning weight data were pooled because the treatment $X$ year interaction was not significant. Cow death loss, calf death loss, and cows culled for health reasons were assumed to be random events because none of these losses could be attributed to the imposed treatments. To maintain consistency, aggregate supplemental hay and feed, as well as labor demands, were also pooled across years.

Partial budgeting techniques were used to formulate a net return function for each treatment. Individual calf weaning weights and 1990 feeder calf prices (Wellman 1991) were used to construct gross returns. Prices for weaned calves were based on sex and weight. The partial budgeting cost function consisted of the following parameters::

Cost $/$ hd $=$ WHay*PHay + WSup*PSup + WRange*PLand + WMeadow*Pland + WMachine Cost + WLabor Cost + MHay*PHay + MMeadow $*$ PLand + MMachine Cost + MLabor Cost,

Where: $\mathbf{W}$ denotes Winter, $P$ denotes Price, and $M$ denotes May.

Hay and protein supplement were charged at their market value to encompass opportunity costs. A land charge was imposed on cows grazing winter range or winter meadows at a rate of half the preceding summer range rental rate on an animal unit month (AUM) basis. An active winter grazing market does not exist; therefore, sensitivity of the results to 25 and $75 \%$ of summer rental rate was examined. The alternative winter pasture rates had no impact on the overall results; therefore, $50 \%$ of summer rate was used. A land charge was imposed on grazing cattle because cows being fed hay are implicitly charged for land through the hay. The land charge for grazing winter meadows was adjusted upwards, because meadows provide more of the animal's protein requirement than range. The machinery complement for feeding hay included a 100 horsepower tractor pulling a stack mover/feeder. The stack mover is capable of feeding a 6.4 metric ton stack and, assuming a feeding rate of $16 \mathrm{~kg}$ of hay ${ }^{\circ} \mathrm{cow}^{-1} \cdot \mathrm{day}^{-1}$, can feed a herd of 400 animals with a single pass; therefore, a 400 cow herd size was assumed for all treatments. Protein supplement was assumed to be fed using a feed truck. Spring costs were handled in a similar manner, except cow/calf pairs grazing meadows in May were charged for land at a rate equal to the summer rental rate. Net returns are returns to factors of production such as health manage-

Table 3. Hay and supplement inputs during gestation, calving and prebreeding of cows on various forage treatments.

\begin{tabular}{lccc}
\hline Treatments $^{\mathrm{a}}$ & Gestation & Calving & Prebreeding \\
\hline & $\ldots$ & $\ldots \ldots+\mathrm{kg} / \mathrm{cow}$ & $\ldots$ \\
Winter range - May hay & 70 supplement & 1188 hay & 614 hay \\
Winter range - May meadow & 70 supplement & 1188 hay & \\
Winter hay - May hay & 1418 hay & 1188 hay & 614 hay \\
Winter hay - May meadow & 1418 hay & 1188 hay & \\
Winter meadow - May hay & 27 supplement & 1188 hay & 614 hay \\
Winter meadow - May meadow & 27 supplement & 1188 hay & \\
\hline
\end{tabular}

a Weights for hay fed is based on records obtained during 1991 and 1992. 
Table 4. Cow body weight, body condition score, and pregnancy rate of 6 forage treatments over 4 years.

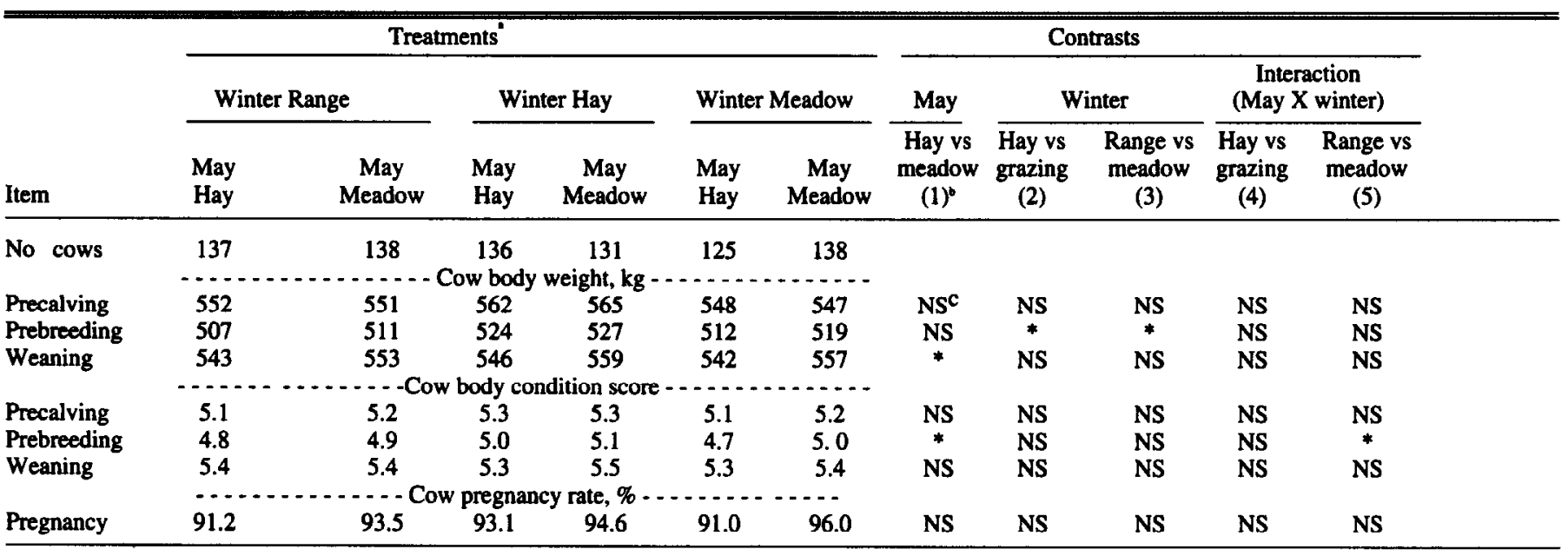

a All year effects were significant $P<0.01$; all treatment $X$ year interactions were nonsignificant $P>0.05$; data not shown

Numbers in parentheses are contrasts as shown in Table 2.

c NS = Not significant $P>0.05$.

* Significant $P<0.05$.

ment (veterinarian, vaccinations), production risk (cow death loss, conception), unpaid family labor, labor not attributed to treatment differences, summer grazing, hay fed during calving, equipment, and overhead.

Nutrient requirement tables (NRC 1984) show that cows fed hay containing $8 \%$ protein and 55\% Total Digestible Nutrients (TDN) require $11.3 \mathrm{~kg}^{\circ}$ head $^{-1} \bullet$ day $^{-1}$ during gestation and $14.4 \mathrm{~kg}$ head $^{-1} \bullet$ day $^{-1}$ during lactation ( $9 \mathrm{~kg}$ milk/day), as fed basis. Over the study period, observed feeding rates for hay averaged $13.5 \mathrm{~kg}^{\circ}$ head $^{-1} \bullet$ day ${ }^{-1}$ over winter and $19.8 \mathrm{~kg}^{\circ}$ head $^{-1}$-day ${ }^{-1}$ between calving and breeding, representing a feeding regime of $120 \%$ and $140 \%$ of estimated requirements (NRC 1984) for gestation and lactation, respectively. While some hay wastage is unavoidable, a best attainable hay feeding rate of $110 \%$ nutrient requirements during gestation and lactation was assumed for treatments being fed hay for the economic analysis. Assuming hay was fed at $110 \%$ NRC requirements biases the results in favor of the treatments being fed hay; however, the assumption allows the analysis to occur assuming high feeding efficiency for all treatments.

Sensitivity of the treatments to input price variability was examined by using a time series of hay prices, supplement prices, and pasture rental rates over the period of 1981-1990 (Johnson and Schroeder 1991, Nebraska Agricultural Statistics 1982-1991). The annual input prices represent 10 separate observed price relationships. The observed input prices were used in all possible combinations ( 10 hay prices $X 10$ supplement prices $X 10$ land rental prices) to create 1,000 input price scenarios with each price scenario assumed to be equally likely. Since the treatment $X$ year interaction for weaning weight was not significant, only a single output price was used in the analysis. The 1,000 input-price scenarios were then coupled with calf weaning weight and calf price to estimate cumulative distribution functions of net returns for each treatment. Common least squares was then used to estimate linear cumulative distribution functions by regressing observations on net returns. The regression procedure has the advantage of simplifying the presentation of cumulative net returns while not altering the relative positions of any of the treatments.

Stochastic approximation methods were used to rank treatments as represented by the regressed, cumulative distribution functions (King and Robison 1984). Stochastic dominance involves pair-wise comparisons of the cumulative distribution functions for net returns of each of the 6 treatments. Ranking of treatments by first degree stochastic dominance (FSD) requires only one assumption, the decision maker prefers more returns to less. First-degree stochastic dominance of one treatment over another holds if the dominating treatment has a greater return at all probability levels compared to the dominated treatment(s). In practice, the cumulative distribution functions are plotted (e.g., Fig. 1). A function that lies completely to the right of another, without any intersections, has FSD over that other curve. The implication for FSD is that the dominating treatment not only has higher average returns, but also higher returns for all price combinations. The dominating treatment, therefore, is also the least risky.

If the curves intersect, then FSD is inconclusive and does not imply dominance. Second degree stochastic dominance (SSD) can be used in some cases to rank treatments when curves intersect. In addition to the assumption of preferring more to less, SSD requires that the decision maker be risk averse. A risk averse individual is willing to give up some potential "uncertain" gain for some lesser "certain" gain. Under SSD, treatment A will dominate treatment B if the accumulated area under the cumulative distribution function for $A$, at all points, is less than or equal to the accumulated area under treatment B's function.

\section{Results and Discussion}

Three of the 4 years of the study were below the 30-year average in annual precipitation and 1 year was near the long term average. Annual precipitation during 1989, 1990, 1991, and 1992 was 203 $\mathrm{mm}, 367 \mathrm{~mm}, 551 \mathrm{~mm}$, and $433 \mathrm{~mm}$, respectively, compared to a 30year average of $535 \mathrm{~mm}$.

\section{Animal Performance}

Amounts of supplement and hay fed are given in Table 3. Hay fed during a year varied from $3,220 \mathrm{~kg} / \mathrm{cow}$ for cows fed hay during winter, after calving, and during May, to $1,188 \mathrm{~kg} / \mathrm{cow}$ for cows that grazed winter range or winter meadow and grazed meadow during May. 
Cow body weight, body condition score, and pregnancy rate are given in Table 4. Interactions between treatment and year and between winter treatments and May treatments were nonsignificant ( $P>0.05$ ) for body weight, body condition, and pregnancy rate of cows. Cow body weight and body condition varied by year. Year effects were not considered large.

Precalving cow weights were similar $(P>0.05)$ for all contrasts. Prebreeding cow weights were greater $(P<0.05)$ for cows fed meadow hay during winter than for cows on winter grazing treatments (526 kg vs $512 \mathrm{~kg}$ ), and cows that grazed winter meadows were heavier $(P<0.05)$ than cows that grazed winter range $(516 \mathrm{~kg}$ vs 509 $\mathrm{kg}$ ). At weaning, cows that grazed meadows in May were heavier $(P<0.05)$ than those fed hay in May $(556 \mathrm{~kg}$ vs $544 \mathrm{~kg})$. Although differences in body weight of cows was observed between forage ing $(P<0.01 ; 90.6 \mathrm{~kg}$ vs $93.7 \mathrm{~kg})$ and weaning $(P<0.05 ; 232 \mathrm{~kg}$ vs $237 \mathrm{~kg}$ ) than calves from cows that grazed meadow during the winter. At prebreeding calves from cows fed hay during winter were heavier $(P<0.01)$ than calves from cows grazing range and meadow during winter ( $94.7 \mathrm{~kg}$ vs $92.1 \mathrm{~kg}$ ), but the difference was not evident at weaning.

\section{Economic Performance}

Partial budgeting costs and returns for each treatment, along with the relevant cost ranges, are illustrated in Table 6. Although the average calf weaning weight was highest for winter-hay, May-meadow system, the average gross return was highest for winter-meadow, May-meadow system. This can be explained by the distribution of weaning weights and because prices used for calves are reported in

Table 5. Calf birth date and body weight of 6 forage treaments over 4 years

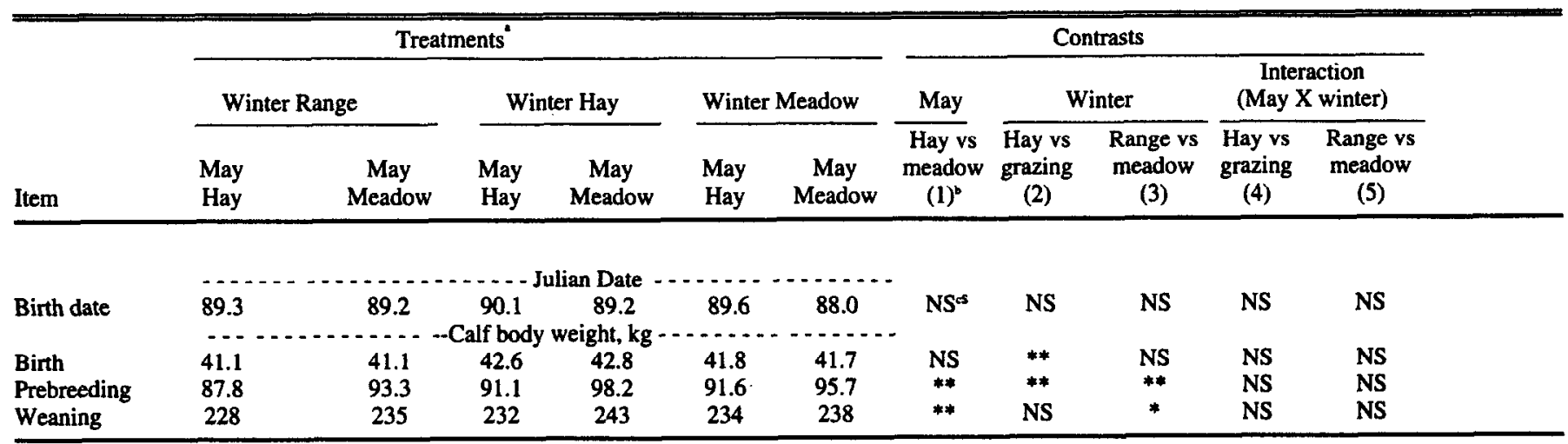

a All year effects were significant $P<0 \quad 01$; all treatment $X$ year interactions were nonsignificant $P \simeq 0.05$; data not shown.

b Numbers in parentheses are contrasts as shown in Table 2.

NS = Not significant $P>0.05$.

* Significant $P<0.05$.

** Significant $P<0.01$.

systems during the 4-year study, differences were small and seasonal and did not increase over time.

Although significant differences in body condition occurred precalving, prebreeding and at weaning, differences were small $(0.1$ to 0.2 score); and cows on all treatments maintained a body condition score near 5.0 during the study. A body condition score of 5.0 is considered moderate and adequate for a high pregnancy rate (Richards et al. 1986). The relatively small variation in body condition score throughout the year for all treatments indicates that each of the forage systems was effective in meeting nutrient requirements of the cow.

Pregnancy rate averaged $93.2 \%$ over the 4 years and across all treatments and was similar to pregnancy rates reported for a 70-day breeding season in the sandhills (Deutscher et al. 1991). All contrasts for pregnancy rate were nonsignificant $(P>0.05)$.

The treatment $X$ year interaction was nonsignificant for calf birth date and all body weights (Table 5). Date of birth (an indicator of breeding date) was nonsignificant $(P>0.05)$ for all contrasts and years. The year effect was significant $(P<0.05)$ for each body weight; but the largest difference between years at weaning was $5 \mathrm{~kg}$. Calf birth weights were greater $(P<0.01)$ for calves from cows fed winter hay than for calves from cows that grazed meadow or range during the winter $(42.7 \mathrm{~kg}$ vs $41.4 \mathrm{~kg}$ ). Calves that grazed meadow in May were heavier $(P<0.01)$ at prebreeding $(95.7 \mathrm{~kg}$ vs $90.2 \mathrm{~kg})$ and weaning ( $237 \mathrm{~kg}$ vs $232 \mathrm{~kg}$ ) than calves on the May hay treatment. Calves from cows that grazed range during winter were lighter at prebreed- one-hundred pound (cwt) increments (Wellman 1991). Weaning weights for winter-hay, May-meadow system were skewed slightly left, while weaning weights for calves in winter-meadow, Maymeadow system were skewed slightly right. The distribution differences and price steps were sufficient to increase gross returns for winter-meadow, May-meadow treatment over gross returns for winter-hay, May-meadow system.

Regression lines illustrating the cumulative set of partial budgeting returns are shown in Figure 1. The cumulative distributions in Figure 1 show the percent of the 1,000 price scenarios which resulted in a given level of net returns for the given output price. For example, for the given output price, $60 \%$ of the price scenarios resulted in net returns of between $\$ 353$ and $\$ 397$ per calf for winter-hay, May-hay and net returns of between $\$ 445$ and $\$ 458$ per calf for winter-meadow, May-meadow. Cows on winter-hay, May-hay exhibited the lowest returns for all price scenarios while cows on winter-meadow, May-meadow exhibited the highest returns. Winter-range, Maymeadow was second best choice. Winter-meadow, May-hay dominated the remaining systems for all price scenarios and winter-range, May-hay dominated winter-hay, May-meadow over approximately $70 \%$ of the price scenarios.

In terms of efficiency, winter-meadow, May-meadow has first degree stochastic dominance over all other systems because its cumulative distribution of net returns always had higher values relative to all other systems. Decision makers preferring winter-meadow, May-meadow have a strict preference of more returns to less returns. Likewise, the winter-range, May-meadow had FSD over all systems 
Table 6. Partial budgeting return and cost ranges per calf by forage system.

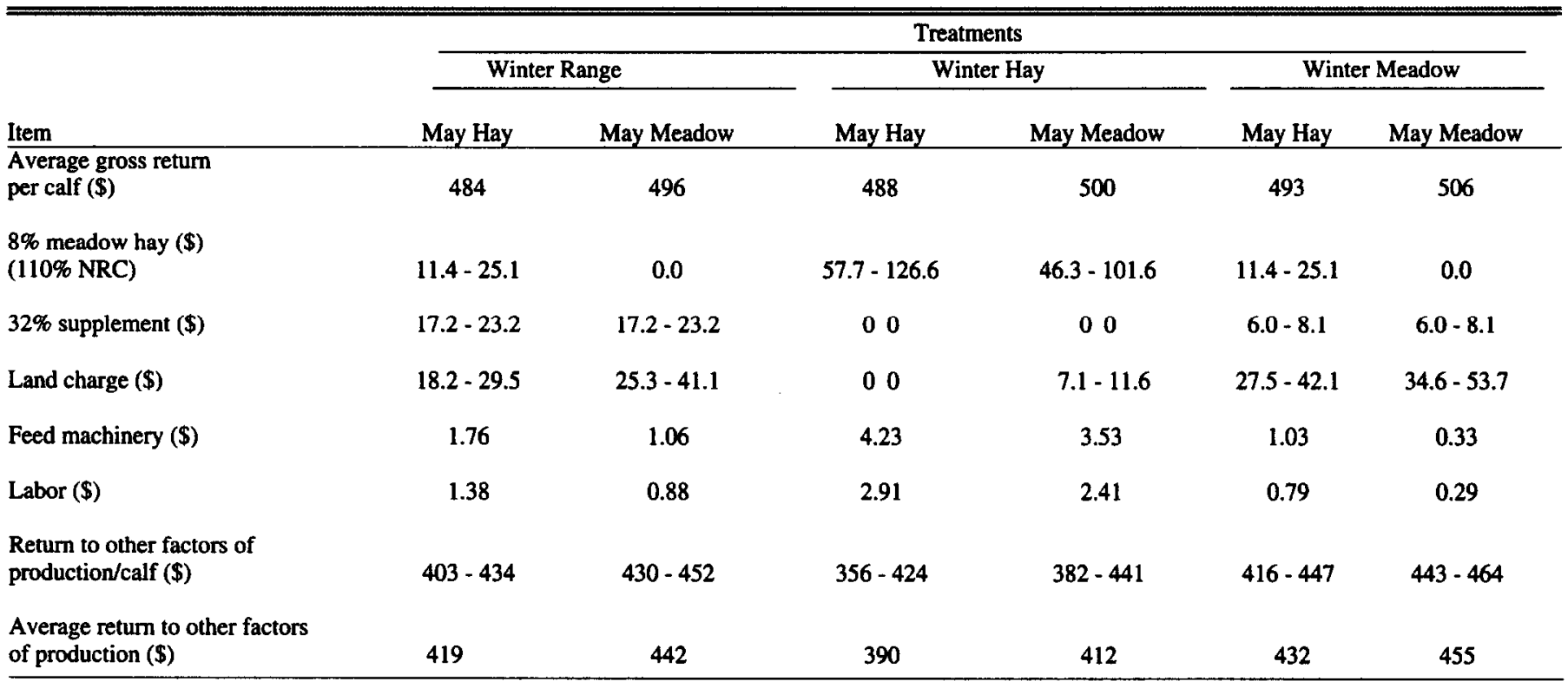

except the winter-meadow, May-meadow; and winter-meadow, Mayhay had FSD over winter-range, May-hay; winter-hay, May-hay; and winter-hay, May-meadow. Because winter-range, May-hay did not exceed winter-hay, May-meadow at all possible outcomes, winterrange, May-hay did not have FSD over winter-hay, May-meadow. However, as the number of outcomes increase, the accumulated area underneath the graph of winter-range, May-hay will always be less than winter-hay, May-meadow; therefore, winter-range, May-hay treatment did exhibit second degree stochastic dominance (SSD) over winter-hay, May-meadow. Decision makers preferring winter-range, May-hay over winter-hay, May-meadow system are risk averse in that winter-range, May-hay will have a greater probability of higher net returns than winter-hay, May-meadow.

The slopes of the regression lines imply that the different treatments have different risk characteristics. Systems with steeper regression lines have less variation in net returns than systems with regression lines having lower slopes. Winter-hay, May-hay and winter-hay, May-meadow systems exhibited the most variability, while the 4 systems without winter-hay exhibited the least variability. The variability in returns is due principally to the fact that feed costs for systems with winter-hay are heavily dependent on hay price while feed costs for the other systems relied principally on supplement and land rental rates. Net returns for treatment with winter-hay were, therefore, based primarily on the 10 hay prices while net returns for those without winter-hay were based primarily on the 100 supplement-land rental rate price scenarios. The relative risk differences between systems with winter-hay and those without winter-hay are therefore due to the diversity in input types and their price variations.

\section{Economic Implications}

Regardless of the winter treatment, grazing meadows in May while upland range is dormant improved economic returns to the cow/calf enterprise. In addition, returns were further improved by having the cow harvest the winter feed by either grazing subirrigated meadows or native range during the winter. The results illustrate that for a ranching operation with adequate meadow and winter range resources, the best forage management strategy involved grazing subirrigated meadows over winter and grazing meadows again in May. However, most ranches face a resource constraint in terms of the availability of subirrigated meadows or winter range. Future research efforts need to be devoted to analyzing the question of how the resource base could impact the forage treatment selection and in particular what the trade-offs are when grazing is substituted for haying on subirrigated meadows.

\section{Literature Cited}

Barkema, A.D. and M. Drabenstott. 1990. A crossroads for the cartle industry. Econ. Rev. Federal Reserve Bank of Kansas City. Nov/Dec. 47-66.

Clark, R.T. and S.A. Coady. 1992. Ranch management practices in the Sandhills of Nebraska: managing the ranch business. Agr. Res. Division, Inst. Agr. and Natur. Resources, Univ. Nebraska-Lincoln, Res. Bull. RB316.

Coady, S.A. and R.T. Clark. 1993. Ranch management practices in the Sandhills of Nebraska: managing production. Agr. Res. Division, Inst. Agr. and Natur. Resources, Univ. Nebraska-Lincoln, Res. Bull. RB-318.

Cox, D.R. 1970. Analysis of binary data. Chapman and Hall, London.

Deutscher, G.H., J.A. Stotts, and M.K. Nielsen. 1991. Effects of breeding season length and calving season on range beef cow productivity. J. Anim. Sci. 69:3453-3460.

D'Souza, G.E., E.W. Marshall, W.B. Bryan, and E.C. Prigge. 1990. Economics of extended grazing systems. Amer. J. Altemative Agr. 5: 120125.

Johnson, B.B. and T. Schroeder. 1990. Nebraska farm real estate market developments 1989-1990. Dep. Agr. Econ., Agr. Res. Division, Inst. Agr. and Natur. Resources, The Univ. Nebraska-Lincoln. Rep. No. 162.

King, R.P., and L. J. Robison. 1984. Risk efficiency models. p.68-81. In: Peter J. Barry (ed.), Risk management in agriculnure. The Iowa State Univ. Press. Ames, Iowa.

Nebraska Agricultural Statistics. Various issues 1982-1991. Nebraska Dep. of Agr., Division Agr. Statistics. Lincoln, Neb.

NRC. 1984. Nutrient Requirements of Beef Cattle, sixth edition. National Research Council, National Academy Press, Washington, D.C.

Rasby, R., M. Frazier, G. Deutscher, I. Rush, T. Mader, J. Gosey, and D. Hudson. 1989. Integrated resource managment. p.1-9. In: 1990 Beef Cattleman Roundup. Nebraska Cooperative Extension. Univ. NebraskaLincoln, Inst. Agr. and Natur. Resources, WCC 90-1, Lincoln, Neb.

Richards, M.W., J.C. Spitzer, and M.B. Warner. 1986. Effect of.varying levels of postpartum nutrition and body condition at calving on subsequent reproductive performance in beef cattle. J. Anim. Sci. 62:300-306.

Wellman, A.C. 1991. Crop and Livestock Prices for Nebraska Producers. Nebraska Cooperative Ext. Serv. Univ. Nebraska-Lincoln, Inst. Agr. and Natur. Resources. EC91-883, Lincoln, Neb. 